\section{Enhanced Production of an Extracellular Lipase by EMS and MMS-Induced Mutant Strain of Rhizopus oligosporus EM-7 using Almond Meal as a Basal Substrate}

\author{
Amna Waseem, Sikander Ali* and Syeda Wajiha Khalid \\ Institute of Industrial Biotechnology (IIB), GC University Lahore, Pakistan
}
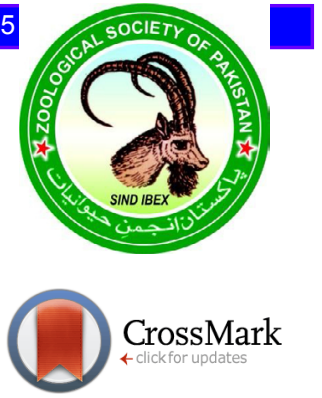

CrossMark

\begin{abstract}
A B S T R A C T
The present study describes the screening and production of extracellular lipase (EC 3.1.1.3) from a Rhizopus oligosporus mutant strain developed by chemical mutagenesis. The wild-type was simultaneously treated with different concentration of EMS and MMS. Among 13 mutant variants, EM-7 showing maximum lipase activity of $71 \pm 3.55 \mathrm{U} / \mathrm{g}$, was selected. Resistance in the hyper producing strain was developed by exposing it with low levels of L-cysteine $\mathrm{HCl}$ to protect it from instability. It was observed that under optimum conditions at $30^{\circ} \mathrm{C}$ temperature, $\mathrm{pH} \mathrm{7}$, and incubation period $64 \mathrm{~h}$, the lipase activity was increased up to $124 \pm 2.48 \mathrm{U} / \mathrm{g}$. The crude enzyme was purified by ammonium sulfate precipitation method at $40 \%$. The molecular weight of the enzyme was found to be $33 \mathrm{kDa}$. The results showed that the enzyme produced from mutant strain gave significantly higher $(\mathrm{p} \leq 0.05)$ lipase activity than the wild-type. From the results presented in the study, it was observed that maximum lipase activity could effectively be achieved after EMS and MMS-induced mutagenesis of filamentous fungus culture used.
\end{abstract}

Article Information
Received 28 January 2017
Revised 24 July 2017
Accepted 28 March 2018
Available online 17 August 2018
Authors' Contribution
Bench work was potentially done by
AW and SWK while SA supervised
and wrote the final draft of the paper.
Key words
Lipase, Ethyl methanesulfonate,
Methyl methanesulfonate, Rhizopus
oligosporus, Solid state fermentation,
Ammonium sulphate precipitation.

\section{INTRODUCTION}

$\mathrm{L}$ ipase (EC 3.1.1.3) is a versatile enzyme which hydrolyzes lipids known as triacylglycerol into fatty acid and glycerol. It represents the class, hydrolases which catalyze the cleavage of substrate by water. The reaction includes cleavage of ester bonds in lipids by lipase (Ramos-Sánchez et al., 2015). It is the third most broadly used enzymes in the industrial level after proteases and cellulases. They are used in industrial scale due to their diversity, properties and substrate specificity (Houde et $a l ., 2004)$. For industrial uses, there are three enzyme sources i.e., animal (mammalian), plant and microbial. Currently, microbes are preferred as they are easy to purify, reproduce fast and are cost effective when compared to other sources (Ivanna et al., 2012; Devaraj et al., 2018). The productive species for lipases include Aspergillus, Penicillium, Rhizopus, Geotrichum and Mucor. Rhizopus oligosporus produce a high-value compound and show high productivity, and thus have a wide range of applications in waste treatment, pharmaceuticals, chemical manufacturing, citric acid production and food industry (Nwuche et al., 2011). Lipases are a useful tool which are being used in food industries such as dairy, fat and oil,

\footnotetext{
Corresponding author: dr.sikanderali@gcu.edu.pk 0030-9923/2018/0005-1929 \$ 9.00/0

Copyright 2018 Zoological Society of Pakistan
}

bakery, meat, beverages and nonfood industries such as detergents, paper and pulp, fine chemicals, pesticides cosmetics and biodiesel production industries (Aravindan, 2006; Mohammadi et al., 2016).

Microbial lipases are produced mostly in submerged fermentation method (SMF) but solid substrate fermentation (SSF) is also a promising technique for enzyme production (Haq et al., 2002; Riyadi et al., 2017). SSF is an eco-friendly procedure than SMF because of its low operating and media cost, greater and non-complicated operating system. It is an effective method for antibiotic and enzyme production at an industrial scale. Mutation can improve a culture to produce enzymes at possible low cost. A mutant strain of fungi can be obtained by physical or chemical mutagenesis (Darvishi et al., 2011). The aim of the present work was to enhance the production of an extracellular lipase from a mutant strain of Rhizopus oligosporus using almond meal as substrate and its purification by ammonium sulfate precipitation. After isolation and screening, the better wild-type (isolate Isl-9) was selected for treatment with different concentrations of EMS and MMS as mutagenic chemicals. Later, resistance against instability in the hyper producing strain (mutant EM-7) was targeted by exposing it with low levels of L-cysteine $\mathrm{HCl}$. The process parameters viz. substrate level, moisture content, $\mathrm{pH}$ and time of incubation were planned to be optimized prior to purification of the enzyme from fermented mash culture. 


\section{MATERIALS AND METHODS}

The chemicals used in the present study were of analytical grade and procured directly from Fluka (UK) and Sigma (USA). Reagents and other solutions were also of the highest possible purity.

\section{Isolation and screening of Rhizopus oligosporus strains}

Different strains of $R$. oligosporus were isolated from food samples i.e., grapes, pickles, sweets, gravy along with different soil samples by making appropriate suspensions and serially diluting the samples $\left(10^{-5}-10^{-6}\right)$. The strains were screened on the basis of their growing capacity in the presence of $1 \mathrm{ml} / \mathrm{L}$ olive oil. The selected strains were sub cultured to purify, and were screened by growing on a PDA medium containing $5 \mathrm{ml} / 1$ olive oil and $1.5 \mathrm{~g} / \mathrm{l}$ oxgall. After 2-3 days of incubation, the colonies having larger olive oil hydrolysis zones were selected, transferred to PDA slants and stored at $4^{\circ} \mathrm{C}$.

\section{Inoculum preparation}

The monoxal OT $(0.05 \%)$ solution was prepared and $10 \mathrm{ml}$ of it was added to a $24 \mathrm{~h}$ old slant culture of $R$. oligosporus and a homogenous spore suspension was prepared. The spore count was made on a haemocytometer slide bridge (Neubier, Germany) and adjusted at $1.25 \times 10^{6}$ $\mathrm{CFU} / \mathrm{ml}$

\section{Solid state fermentation technique}

The almond meal (dried at $70^{\circ} \mathrm{C}$ for $2 \mathrm{~h}$ ) obtained from the local grocery shop was used as a substrate for lipase production by solid state fermentation. Ten grams almond meal and 10 milliliter distilled water were added in a 1:1 ratio to a $250 \mathrm{ml}$ cotton plugged flask and autoclaved (Wiseclave, China) at $121^{\circ} \mathrm{C}$ for $15 \mathrm{~min}$. The flasks were inoculated by $1 \mathrm{ml}$ inoculum aseptically and incubated at $30^{\circ} \mathrm{C}$ for $72 \mathrm{~h}$.

\section{Analytical techniques}

Enzyme extraction

After the fermentation process, $50 \mathrm{ml}$ of distilled water was added to the flask and incubated in a rotary shaker $(160 \mathrm{rpm})$ at $30^{\circ} \mathrm{C}$ for $1 \mathrm{~h}$. The contents of the flask were filtered using a piece of muslin cloth and the absorbance was measured by a UV/Vis spectrophotometer (UV 5100B, China) at $595 \mathrm{~nm}$.

\section{Lipase assay}

One milliliter enzyme extract was added to the 17 $\mathrm{ml}$ reaction mixture $(10 \%$ olive oil in $10 \%$ gum acacia, $2 \mathrm{ml} \mathrm{CaCl}, 5 \mathrm{ml}$ phosphate buffer $\mathrm{pH}$ 7) and incubated in a shaking incubator at $30^{\circ} \mathrm{C}$ for $60 \mathrm{~min}$ on $160 \mathrm{rpm}$.
Later, $10 \mathrm{ml}$ of alcohol and $10 \mathrm{ml}$ of acetone mixture was added to stop the reaction and mixed well. Few drops of phenolphthalein were added as an indicator. The mixture was titrated against $0.1 \mathrm{~N} \mathrm{NaOH}$, till appearance of light pink color (Kundu and Pal, 1970). One unit of activity is defined as the amount of enzyme, which releases $1 \mu$ mole of fatty acids per minute per milliliter under specified assay conditions.

$$
\text { Lipase activity }(U / g)=\frac{\Delta V+N \times 1000}{V(\text { sample })} \times 60
$$

Where, $\Delta \mathrm{V}=\mathrm{V}_{2}-\mathrm{V}_{1}$ is the volume of $\mathrm{NaOH}$ used against control flask, $\mathrm{V}_{2}$ is the volume of buffer used against experimental flask, $\mathrm{N}$ is normality of $\mathrm{NaOH}$ and $\mathrm{V}_{\text {sample }}$ is volume of extract.

Chemical mutagenesis and resistance development in selected mutant strain

Fungal inoculum was prepared in $50 \mathrm{ml}$ of Vogel's medium for $48 \mathrm{~h}$, Whattman filter paper was used to filter mycelial biomass. After washing biomass 2-3 time with phosphate buffer, it was stored in the buffer at $4^{\circ} \mathrm{C}$. This seed culture was mutated by different concentrations $(0.5$ $3 \mathrm{mM}$ ) of EMS and for different time intervals from 5 to $30 \mathrm{~min}$. One milliliter sodium thiosulphate $(0.1 \mathrm{mM})$ was added to terminate the reaction. The falcon was centrifuged aseptically at 3,500 rpm for $20 \mathrm{~min}$. The supernatant was discarded and pellet was washed with sterilized phosphate buffer, re-centrifuged and suspended in falcon tubes containing sterilized MOT. After that same method was adopted for treating the EMS mutant with MMS (0.5-3 $\mathrm{mM}$ ) concentration. The culture showing maximum lipase activity after $48-72 \mathrm{~h}$ was selected. It was transferred to PDA slant and stored at $4^{\circ} \mathrm{C}$ after growth.

The selected mutant strain was developed for better resistance against various low concentrations (0.05-0.3 $\mu \mathrm{M})$ of L-cysteine $\mathrm{HCl}$ at different incubation period (5-30 min) by taking $2.5 \mathrm{ml}$ of inoculum and $2.5 \mathrm{ml}$ of L-cysteine $\mathrm{HCl}$ in a falcon tube. It was incubated at $30^{\circ} \mathrm{C}$ and centrifuged at 3,000 rpm for $20 \mathrm{~min}$. The supernatant was discarded carefully and the pellet was suspended in sterilized phosphate buffer ( $\mathrm{pH} 7)$.

Optimization of production parameters for thermophilic lipase

Various levels of solid substrate ranging from 5 to $25 \mathrm{~g}$ at different level of moisture content $(5-30 \mathrm{ml})$ were evaluated. The initial $\mathrm{pH}$ of growth medium ranging from 6.6 to 7.8 with $1 \mathrm{~N} \mathrm{HCl}$ or $\mathrm{NaOH}$ before sterilization was examined. To enhance lipase activity, different incubation time (12 to $96 \mathrm{~h}$ ) periods were compared. 
Table I.- Sub-grouping of lipase producing by isolates* and mutant strains ${ }^{\$}$ of $R$. oligosporus developed through alternative chemical EMS and MMS treatment.

\begin{tabular}{cc}
\hline R. oligosporus strain & Range of lipase (U/g) \\
\hline Isolates & $1.0-5.0$ \\
4 & $6.0-10$ \\
6 & $11-15$ \\
2 & $16-20$ \\
3 & $21-25$ \\
3 & $26-30$ \\
$2^{*}$ & \\
EMS mutants strain & $1-10$ \\
9 & $11-20$ \\
13 & $21-30$ \\
20 & $31-40$ \\
20 & $41-50$ \\
$3^{*}$ & \\
MMS mutant strain & $31-40$ \\
3 & $41-50$ \\
5 & $51-60$ \\
10 & $61-70$ \\
7 & $71-80$ \\
1 & \\
L-cysteine HCl resistant & $30-40$ \\
2 & $41-50$ \\
4 & $51-60$ \\
3 & $61-70$ \\
2 &
\end{tabular}

Almond meal $15 \mathrm{~g}, 1 \mathrm{M}$ tris- $\mathrm{HCl} 12.5 \mathrm{ml}, \mathrm{pH} 7$, incubation time $72 \mathrm{~h}$, temperature $30^{\circ} \mathrm{C}$, beef extract $0.2 \%$, olive oil $1 \%$. * Only two strains gave lipase production in the range of $26-30 \mathrm{U} / \mathrm{g}$ and they were coded as Isl-3 and Isl-9. Isl-9 was selected for alternative treatment by EMS/ MMS. ${ }^{5}$ The mutant strain of $R$. oligosporus EM-7 being the best producer of lipase $(72 \mathrm{U} / \mathrm{g})$ was selected for resistance development through L-cysteine $\mathrm{HCl}$.

\section{Study of kinetic parameters}

Pirt (1975) and Lawford and Roseau (1993) techniques were used to study the kinetic parameters for fermentation process. Specific growth rate $(\mu)$ was calculated from plots of $\operatorname{In}(\mathrm{X})$ vs. incubation period. The product yield coefficient was determined by the growth rate divided by product, $\mathrm{Y}_{\mathrm{p} / \mathrm{x}}(\mathrm{g} / \mathrm{g}$ cells $)=\mathrm{dP} / \mathrm{dX}$.

\section{Statistical analysis}

Least significant difference after one way ANOVA (SPSS, version 24) was used to compare the treatment effects (Snedecor and Coehran, 1980). Significant difference among replicates has been represented as Duncan's multiple ranges in the form of probability $(<\mathrm{P}>)$ values.

\section{Partial purification of lipase}

The enzyme was purified by ammonium sulfate precipitation (40-80\%) method. Centrifugation was done at 4,500 for $15 \mathrm{~min}$. The pellets obtained were dissolved in $0.5 \mathrm{M}$ Tris $\mathrm{HCl}(2 \mathrm{ml})$ buffer having $\mathrm{pH}$ 8. Dialysis was done overnight using membrane at $4^{\circ} \mathrm{C}$ to remove excessive ammonium sulfate salt.

\section{Molecular mass determination by SDS}

The enzyme molecular weight was determined by SDS PAGE. Polyacrylamide gel (12\%) was prepared with $1.5 \mathrm{M}$ Tris-HCl buffer, $10 \%$ SDS (nanoPAC-300 Cleaver, Warwickshire, UK), TEMED, $30 \%$ acrylamide mixture and $10 \%$ ammonium per sulfate. The gel was drawn out when the process of electrophoresis finished, and after staining and de-staining steps, vibrant bands of enzyme appeared on the gel.

\section{RESULTS AND DISCUSSION}

Fifty different strains of $R$. oligosporus were isolated from food and soil samples of different area of Lahore and Murree. These were maintained by sub culturing them on PDA slants, $\mathrm{pH}$ 5-6. The primary screening of isolates was done on the basis of the ability to grow on the media containing olive oil. Only 20 out of 50 showed the ability to grow in the presence of olive oil. The secondary screening was performed on the basis of lipase activity by fermentation method as shown in Table I. According to Ramos-Sanchez et al. (2015), $R$. oligosporus was considered as one of the superior enzyme producing organism. In the present study, Isl-9 exhibited greater lipase activity $(30 \pm 1.8 \mathrm{U} / \mathrm{g})$ in $72 \mathrm{~h}$ when incubated at $30^{\circ} \mathrm{C}$, therefore, Isl-9 was selected for EMS or MMS induced chemical mutation.

Sixty five colonies of mutant strains were selected to produce lipase through various concentration of mutagen EMS (0.5-4 mM) on different time ranging from 5 to 30 min. The mutant strain of $R$. oligosporus (code EMS-27) was selected, as it was gave maximum lipase activity $(50 \pm 2.50 \mathrm{U} / \mathrm{g})$. However, any other treatment with higher EMS concentrations, decreased enzyme production. This decline in enzyme activity was due to the reduction of the metabolic activity of the isolate. Thus, the mutant strain EMS-27 was selected for chemical mutation through methane methyl sulfonate (MMS) as a mutagen. Twenty seven colonies of mutant strains were selected to produce enzyme through various concentrations of mutagen MMS (0.5-4 $\mathrm{mM})$ at different time intervals (5 to $30 \mathrm{~min}$ ). The amount of enzyme produced was in the range of $31 \pm 0.25$ to $80 \pm 3.0 \mathrm{U} / \mathrm{g}$ (Table I). The best developed mutant strain (code MMS-16) was selected, as it gave maximum enzyme activity. However, any further treatment with higher MMS concentration decreased the enzyme production due to more than sufficient concentration of the mutagen. 
The selected mutant strain (MS-16) exhibiting better lipase activity was made resistant at various concentration of L-cysteine $\mathrm{HCl}(10-70 \mathrm{mM})$ for different time intervals. Table I shows the effect of L-cysteine $\mathrm{HCl}$ on the enzyme activity. The maximum enzyme activity for EM-7 was $72 \pm 3.60 \mathrm{U} / \mathrm{g}$ in $4 \mathrm{~min}$ as the incubation time at $50 \mathrm{nM}$ L-cysteine $\mathrm{HCl}$. A similar kind of anti-diversion approach was used by Nikaido (2009). Therefore, the mutant strain (EM-7) giving maximum activity was selected for optimization of various process parameters.

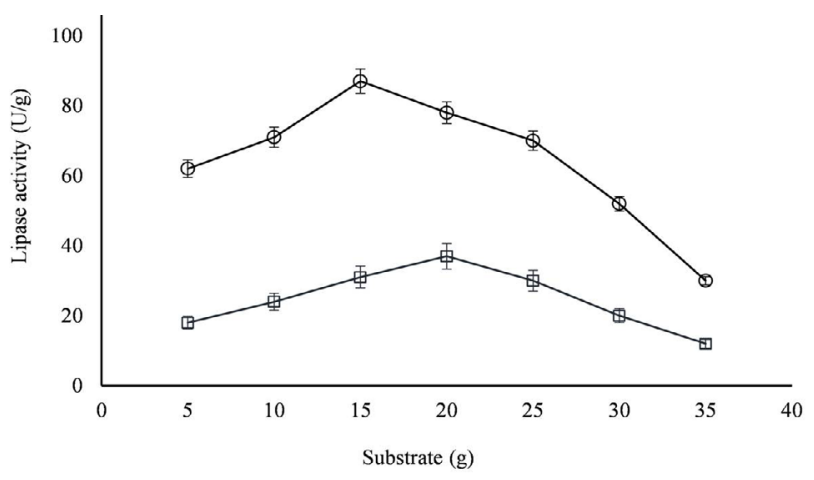

Fig. 1. Effect of different level of substrate on lipase production by wild-type (Isl-9) and mutant strain (EM-7) of $R$. oligosporus. Distilled water $10 \mathrm{ml}$, time of incubation $72 \mathrm{~h}$, temperature $30^{\circ} \mathrm{C}$. - $\square$-, Wild-type Isl-9; -O-, Mutant strain EM-7. Y-error bars state standard deviation $( \pm \mathrm{SD}$ $5 \%$ ) among the values of three parallel replicates.

The effect of different level of substrate on lipase production by Isl-9 and mutant strain of $R$. oligosporus EM-7 is shown in Figure 1. For Isl-9, maximum enzyme activity $(37 \pm 1.85 \mathrm{U} / \mathrm{g})$ was obtained at $20 \mathrm{~g}$ of substrate. However, lipase activity obtained from EM-7 was $87 \pm 4.25$ $\mathrm{U} / \mathrm{g}$ using $15 \mathrm{~g}$ of substrate. Afterwards, any increase in the level of substrate caused a sharp decline ( 2-3 fold) in the lipase activity. Different buffers of varying $\mathrm{pH}$ and distilled water were used for the lipase activity. The buffers used included phosphate $(7.2 \mathrm{pH})$, acetate $(4.8$ $\mathrm{pH})$, Tris- $\mathrm{HCl}(6.8 \mathrm{pH})$, saline solution $(8 \mathrm{pH})$ and $0.1 \mathrm{~N}$ $\mathrm{HCl}(4 \mathrm{pH})$ alongwith distilled water (Fig. 2). Tris- $\mathrm{HCl}$ gave the maximum enzyme activity obtained as $37 \pm 1.85$ $\mathrm{U} / \mathrm{g}$ and $94 \pm 8.25 \mathrm{U} / \mathrm{g}$ by Isl-9 and EM-7, respectively. According to Ekinci et al. (2015), pH has different effect on the activity of enzyme. At an alkaline $\mathrm{pH}$, the enzyme was self-hydrolytic while at an acidic $\mathrm{pH}$, the enzyme gave negligible activity, so moderate $\mathrm{pH}$ was required for better activity. The $\mathrm{pH}$ of Tris- $\mathrm{HCl}$ buffer was changed from 6.6-7.8 to determine the maximum lipase activity of mutant EM-7 and is shown in Figure 2. A better value was obtained at $\mathrm{pH} 7$ i.e., $114 \pm 5.65 \mathrm{U} / \mathrm{g}$, but after that enzyme activity decreased with the rise in the $\mathrm{pH}$ of buffer. The volume of moisture content $(7.5-22.5 \mathrm{ml})$ for both Isl-9 and EM-7 was changed to enhance the enzyme activity and is shown in Figure 3. It was observed that low moisture volume gave less enzyme activity but with the increase in volume the enzyme activity was also increased. The maximum enzyme activity by Isl-9 was obtained at 12.5 $\mathrm{ml}$ of distilled water $(43 \pm 0.84 \mathrm{U} / \mathrm{g})$. However, for EM-7, the maximum activity was obtained at $15 \mathrm{ml}$ of Tris- $\mathrm{HCl}$ buffer $(119 \pm 2.38 \mathrm{U} / \mathrm{g})$. Hence, the moisture content, $\mathrm{pH}$ and volume of moisture content were optimized for both Isl-9 and EM-7 exhibiting maximum enzyme activity.
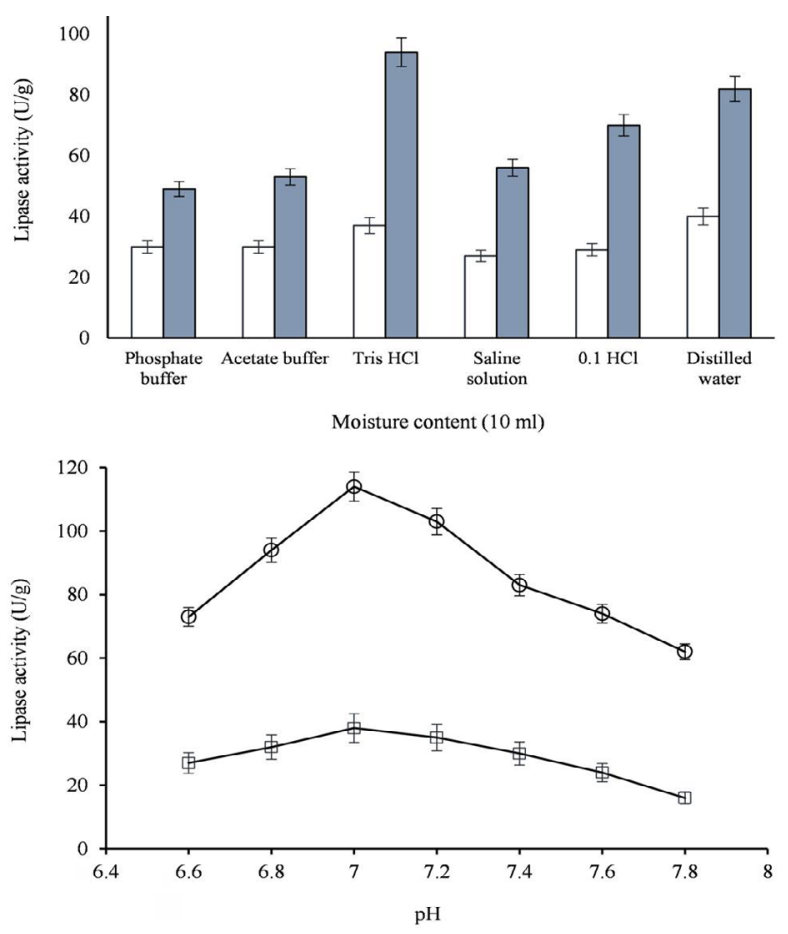

Fig. 2. Effect of different moisture content and $\mathrm{pH}$ on lipase production by wild-type (Isl-9) and mutant strain (EM-7) of $R$. oligosporus. Almond meal $15 \mathrm{~g}$, time of incubation 72 $\mathrm{h}$, temperature $30^{\circ} \mathrm{C}$. Y-error bars state standard deviation $( \pm$ SD $5 \%)$ among the values of three parallel replicates. For symbols, see Figure 1.

The role of time of incubation (8-96 h) on Isl-9 and mutant strain of $R$. oligosporus EM-7 on lipase activity was also studied and is shown in Figure 4. In case of Isl-9 and EM-7, the maximum enzyme activity obtained after $64 \mathrm{~h}$ of incubation time was $49 \pm 0.98$ and $124 \pm 2.48 \mathrm{U} / \mathrm{g}$, respectively. The enzyme activity of EM-7 was 2.5 fold higher than Isl-9. Any further increase in the incubation time caused a remarkable decrease in the enzyme activity. This might be due to the fact that longer incubation 
time might cause reduction in nutrients and enzymatic degradation. Kinetic comparison of specific growth rate of lipase fermentation at 20 and $15 \mathrm{~g} / \mathrm{ml}$ almond meal as a substrate following growth of $R$. oligosporus (Isl-9) and its mutant derivatives (EM-7), respectively was made and is shown in Figure 5. The specific growth rate was progressively decreased with the increase in the incubation time. Comparison of product yield coefficient of lipase production is illustrated in Figure 5. Initially, the value of $\mathrm{Y}_{\mathrm{p} / \mathrm{x}}$ was less, but as the incubation time was increased, the value of $\mathrm{Y}_{\mathrm{p} / \mathrm{x}}$ also increased (Table II). The highest value was obtained at $64 \mathrm{~h}$ and mutant strain E-7 $(63.91 \mathrm{~g} / \mathrm{g}$ cells) had about twice the value than the wild-type (33.56 $\mathrm{g} / \mathrm{g}$ cells).

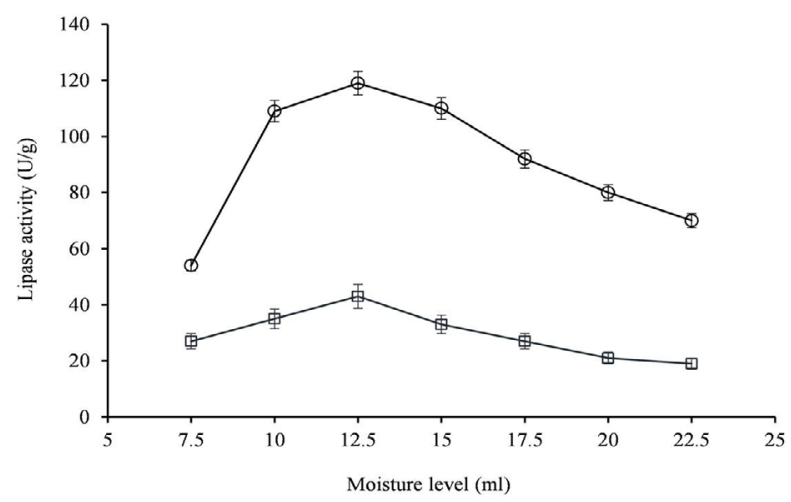

Fig. 3. Effect of moisture level on lipase production by wild-type (Isl-9) and mutant strain (EM-7) of $R$. oligosporus. Almond meal $15 \mathrm{~g}$, moisture tris- $\mathrm{HCl}, \mathrm{pH} 7$, time of incubation $72 \mathrm{~h}$, temperature $30^{\circ} \mathrm{C}$. Y-error bars state standard deviation $( \pm \mathrm{SD} 5 \%)$ among the values of three parallel replicates. For symbols, see Figure 1.

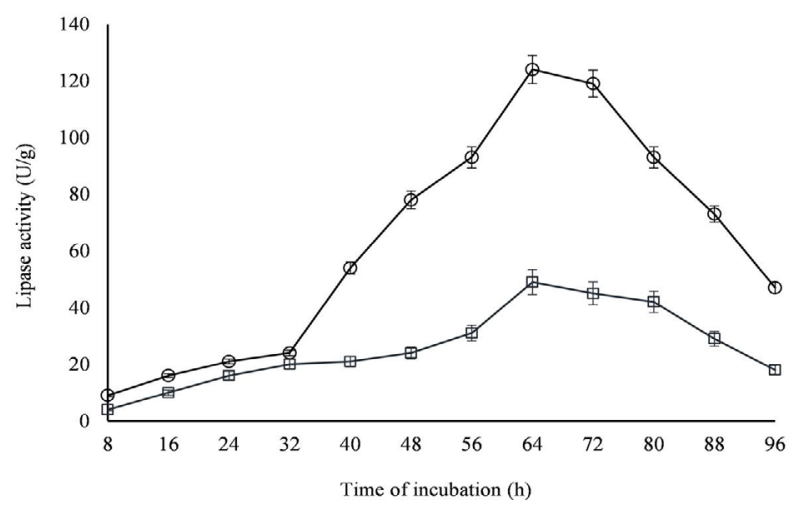

Fig. 4. Time of incubation for lipase production by wildtype (Isl-9) and mutant strain (EM-7) of $R$. oligosporus. Almond meal $15 \mathrm{~g}$, moisture $12.5 \mathrm{ml}$ tris- $\mathrm{HCl}, \mathrm{pH} 7$, temperature $30^{\circ} \mathrm{C}$. Y-error bars state standard deviation $( \pm$ SD $5 \%)$ among the values of three parallel replicates. For symbols, see Figure 1.
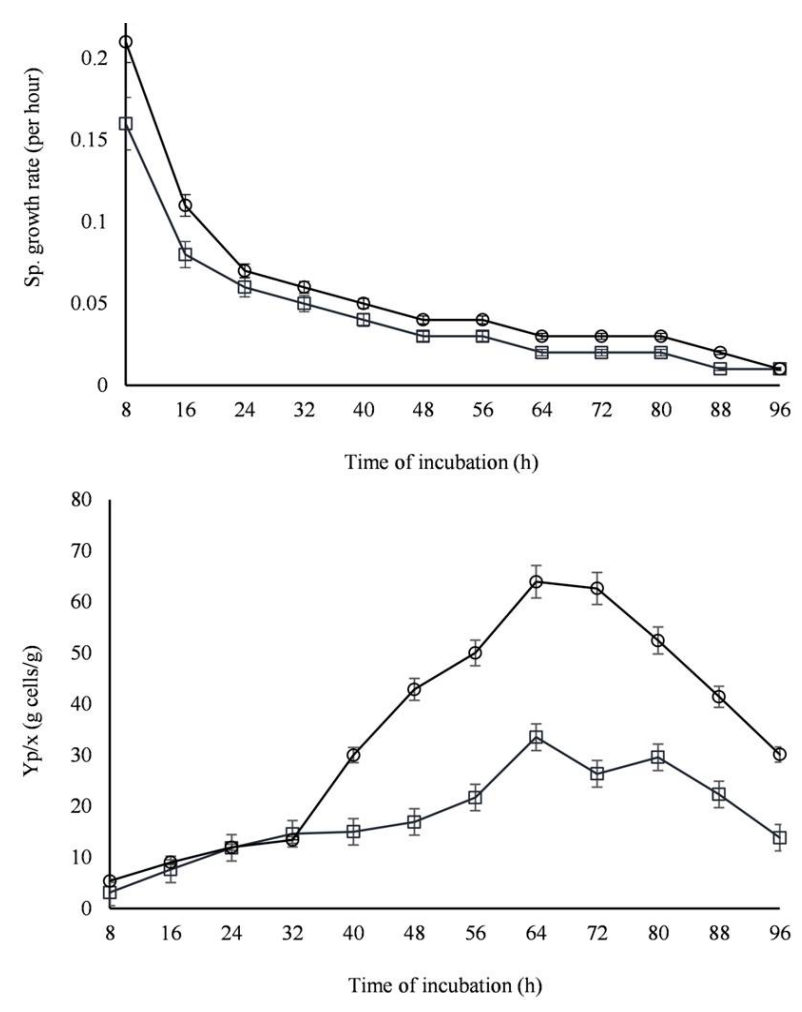

Fig. 5. Kinetics of specific growth rate $\left(\mu \mathrm{h}^{-1}\right)$ and product yield coefficient $\left(\mathrm{Y}_{\mathrm{p} / \mathrm{x}} \mathrm{g}\right.$ cells/g) for lipase production by wild-type (Isl-9) and mutant strain (EM-7) of $R$. oligosporus. Almond meal $15 \mathrm{~g}$, moisture $12.5 \mathrm{ml}$ tris- $\mathrm{HCl}$, $\mathrm{pH} 7$, time of incubation $72 \mathrm{~h}$, temperature $30^{\circ} \mathrm{C}$. Y-error bars state standard deviation ( \pm SD $5 \%$ ) among the values of three parallel replicates. The sum mean values in each set vary significantly at $\mathrm{p} \leq 0.05$. For symbols, see Figure 1 .

Table II.- Comparison of kinetic parameters (specific growth rate, product yield coefficients) for lipase production after $64 \mathrm{~h}$ conidial inoculation.

\begin{tabular}{lcc}
\hline Kinetic parameters & $\begin{array}{c}\text { Wild type } \\
\text { (Isl-9) }\end{array}$ & $\begin{array}{c}\text { Mutant strain } \\
\text { (EM-7) }\end{array}$ \\
\hline $\begin{array}{l}\text { Specific growth rate } \\
\mu\left(\mathrm{h}^{-1}\right)\end{array}$ & $0.02 \pm 0.01$ & $0.03 \pm 0.01$ \\
Product yield coefficient & $33.56 \pm 6.71$ & $63.91 \pm 6.39$
\end{tabular}

$\mathrm{Y}_{\mathrm{n} / \mathrm{x}}(\mathrm{g} / \mathrm{g}$ cells $)$

Kinetic parameter: $\mu\left(\mathrm{h}^{-1}\right)=$ specific growth rate, calculated from plots of $\operatorname{In}(X)$ vs. incubation period, $Y_{p / x}(g / g$ cells $)=d P / d X$. Each value is a mean average of three parallel replicates. \pm specifies standard deviation.

The incubation temperature of fermentation medium has a profound effect on lipase activity (Nwuche et al., 2011). Temperature stability was studied at different temperatures ranging from 30 to $70^{\circ} \mathrm{C}$ and the results are depicted in Figure 6. At low temperatures, the 
enzyme activity remained low as the activation energy was possibly quite high (Massadeh et al., 2012). It was noted that the enzyme was stable at $30^{\circ} \mathrm{C}$ and exhibited maximum lipase activity of $48 \pm 3.55 \mathrm{U} / \mathrm{g}$ by Isl-9 and $121 \pm 9.35 \mathrm{U} / \mathrm{g}$ by EM-7. It was possibly due to the optimal growth of fungal culture which promoted superior enzyme activity as reported by Riyadi et al. (2017). As the temperature increased, the value of enzyme activity decreased by Isl-9 $(19 \pm 1.8 \mathrm{U} / \mathrm{g})$ up to 1.97 fold while by EM-7 $(51 \pm 4.05 \mathrm{U} / \mathrm{g})$ up to 2.08 fold. It was due to the fact that a temperature higher than the optimal might denature the enzyme molecules or disturb the microenvironment of active centre of the enzyme. However, Massadeh et al. (2012) reported the stability of the enzyme produced from Bacillus stearothermophilus HUI to be upto $55^{\circ} \mathrm{C}$.

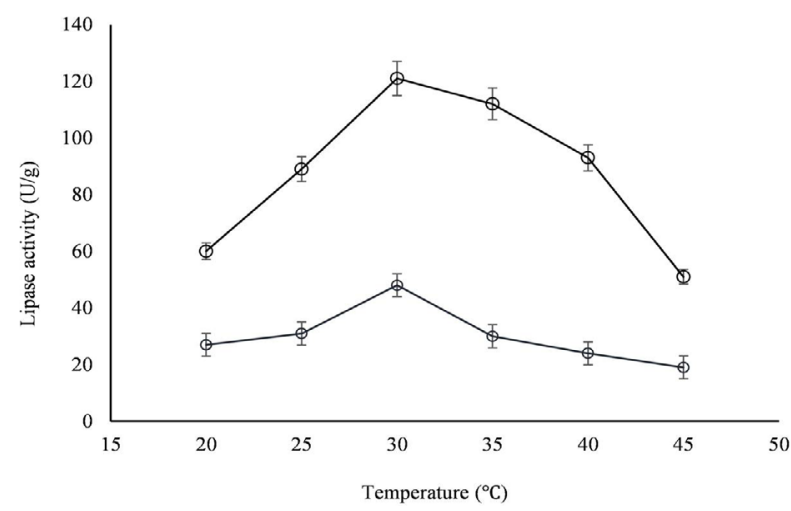

Fig. 6. Effect of temperature on lipase production by wildtype (Isl-9) and mutant strain (EM-7) of $R$. oligosporus. Almond meal $15 \mathrm{~g}$, moisture $12.5 \mathrm{ml}$ tris- $\mathrm{HCl}, \mathrm{pH} 7$, time of incubation $72 \mathrm{~h}$. Y-error bars state standard deviation $( \pm$ SD $5 \%)$ among the values of three parallel replicates. The sum mean values in each set vary significantly at $\mathrm{p} \leq 0.05$. For symbols, see Figure 1 .

The enzyme of mutant strain EM-7 was partially purified by ammonium sulfate precipitation at different saturation level $(20,40,60$ and $80 \%)$. Laats et al. (1997) used ammonium sulfate precipitation method to concentrate the sample, remove impurities and excessive proteins. The crude sample when precipitated at $40 \%$ ammonium sulfate showed maximum lipase activity and protein content of $187 \pm 9.35 \mathrm{mg} / \mathrm{ml}$ and $90 \pm 3.75 \mathrm{U} / \mathrm{ml}$, respectively (Table III). The specific activity was however, noted to be $2.07 \pm 1.03 \mu \mathrm{g} / \mathrm{ml}$. Desalting through dialysis was performed to remove the excessive ammonium sulfate from the protein sample EM-7. A single band of the partially purified enzyme from Isl-9 and EM-7 was obtained that showed the consistency of the partially purified enzyme as shown is Figure 7. The molecular weight of the enzyme both from wild-type (Isl-9) and mutant strain (EM-7) had a molecular weight of $33 \mathrm{kDa}$. In contrast, different molecular weights were reported by other authors such as $31.5 \mathrm{kDa}$ from $R$. oligosporus (Iftikhar et al., 2008) and 26 $\mathrm{kDa}$ from Geobacillus stearothermophilus (Ekinci et al., 2015).

Table III.- Effect of ammonium sulphate concentration on the lipase purification by mutant strain of $R$. oligosporus (EM-7).

\begin{tabular}{lccc}
\hline $\begin{array}{l}\text { Ammonium } \\
\text { sulphate (\%) }\end{array}$ & $\begin{array}{l}\text { Protein } \\
\text { content } \\
(\mathbf{m g} / \mathbf{m l})\end{array}$ & $\begin{array}{c}\text { Lipase } \\
\text { activity } \\
(\mathbf{U} / \mathbf{m l})\end{array}$ & $\begin{array}{c}\text { Specific } \\
\text { activity } \\
(\boldsymbol{\mu g} / \mathbf{m l})\end{array}$ \\
\hline 20 & $85 \pm 3.25$ & $169 \pm 8.45$ & $1.98 \pm 0.95$ \\
40 & $90 \pm 3.75$ & $187 \pm 9.35$ & $2.07 \pm 1.03$ \\
60 & $70 \pm 3.5$ & $131 \pm 6.55$ & $1.87 \pm 0.93$ \\
80 & $40 \pm 3.0$ & $30 \pm 1.50$ & $0.75 \pm 0.37$ \\
\hline
\end{tabular}

Each value is a mean average of three parallel replicates. \pm specifies standard deviation. The sum mean values in each set vary significantly at $\mathrm{p} \leq 0.05$

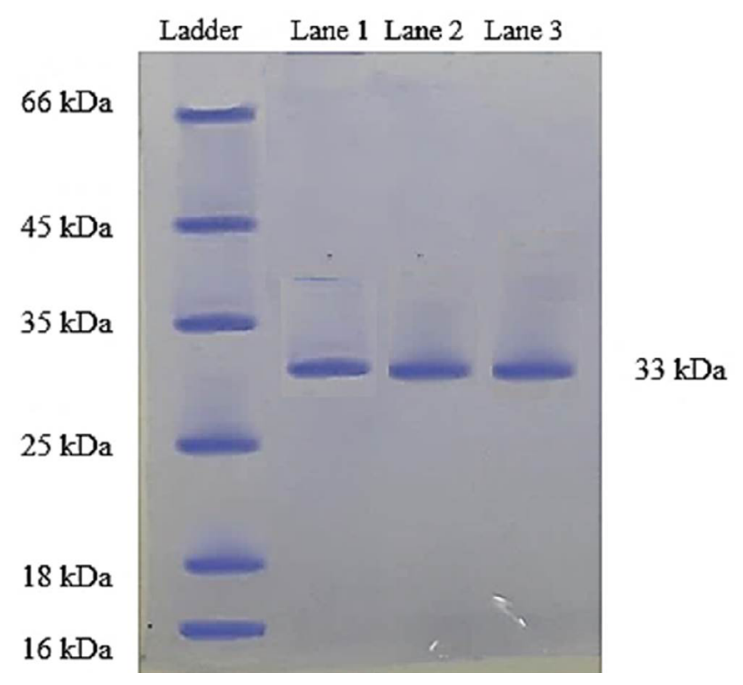

Fig. 7. The molecular weight of lipase isolated from Isl9, crude EM-7 and purified EM-7. Ladder, protein ladder; Lane 1, crude enzyme from Isl-9; Lane 2, crude enzyme from EM-7; Lane 3, partially purified enzyme from EM-7 with molecular weight $33 \mathrm{kDa}$.

\section{CONCLUSIONS}

In the present study, the strain of $R$. oligosporus was isolated from soil samples. The strain Isl-9 was improved to produce extracellular lipase by EMS and MMS as the chemical mutagens. The selected mutant strain gave enzyme production upto 6.2 fold higher than the wild-type and partially purified at $40-80 \%$ ammonium sulfate. 


\section{ACKNOWLEDGEMENTS}

We are grateful to the Vice Chancellor for providing the necessary facilities.

\section{Statement of conflict of interest}

Authors have declared no conflict of interest.

\section{REFERENCES}

Aravindan, R., Anbumathi, P. and Viruthagiri, T., 2006. Lipase applications in food industry. Ind. J. Bot. 6: 141-158.

Chahinian, H., Vanot, G., Ibrik, A., Rugani, N., Sarda, L. and Comeau, L.C., 2000. Production of extracellular lipases by Penicillium cyclopium purification and characterization of partial acylglycerol lipase. Biosci. Biotechnol. Biochem., 64: 215-222. https:// doi.org/10.1271/bbb.64.215

Darvishi, F., Destain, J., Nahvi, I., Thonart, P. and Zarkesh-Esfahani, H., 2011. High-level production of extracellular lipase by Yarrowia lipolytica mutants from methyl oleate. Nature Biotechnol., 28: 756-760. https://doi.org/10.1016/j.nbt.2011.02.002

Devaraj, K., Aathika, S., Periyasamy, K., ManickamPeriyaraman, P., Palaniyandi, S. and Subramanian, S., 2018. Production of thermostable multiple enzymes from Bacillus amyloliquefaciens KUB29. Nat. Prod. Res., 16: 1-4. https://doi.org/10.1080/14 786419.2018 .1425857

Ekinci, A.P., Dinçer, B., Baltas, N. and Adiguzel, A., 2016. Partial purification and characterization of lipase from Geobacillus stearothermophilus AH22. J. Enz. Inhib. Med. Chem., 31: 325-331. https://doi. org/10.3109/14756366.2015.1024677

Haq, I., Idrees, S. and Rajoka, M.I., 2002. Production of lipases by Rhizopus oligosporus by solid-state fermentation. Proc. Biochem., 37: 637-641. https:// doi.org/10.1016/S0032-9592(01)00252-7

Houde, A., Kademi, A. and Leblanc, D., 2004. Lipases and their industrial applications. Appl. Biochem. Biotechnol., 118: 115-170. https://doi.org/10.1385/ ABAB:118:1-3:155

Iftikhar, T., Niaz, M., Afzal, M., Haq, I. and Rajoka, M.I., 2008. Maximization of intracellular lipase production in a lipase-overproducing mutant derivative of Rhizopus oligosporus DGM 31: A kinetic study. Fd. Technol. Biotechnol., 46: 402412.

Ivanna, R., Mateos-Diaz, J.C. and Sandoval, G., 2012. Plant lipases: Partial purification of Carica papaya lipase. Methods Mol. Biol., 861: 115-122. https:// doi.org/10.1007/978-1-61779-600-5_7

Kundu, A.K. and Pal, N., 1970. Isolation of lipolytic fungi from the soil. J. Pharm. Ind., 32: 96-97.

Laats, M.M., Grosdenis, F., Recourt, K., Voragen, A.G. and Wichers, H.J., 1997. Partial purification and characterization of pectin methylesterase from green beans (Phaseolus vulgaris L.). J. Agri. Food Chem., 45: 572-577.

Lawford, H.G. and Roseau, J.D., 1993. Mannose fermentation by ethanologenic recombinants of $E$. coli and kinetic aspects. Biotechnol. Lett., 15: 615620. https://doi.org/10.1007/BF00129327

Massadeh, M., Sabra, F., Dajani, R. and Arafat, A., 2012. Purification of lipase enzyme produced by Bacillus stearothermophilus HU1. International Conference on Eco-systems and Biological Sciences (ICEBS'2012) Penang, Malaysia.

Mohammadi, M., Sepehrizadeh, Z., Ebrahim-Habibi, A., Shahverdi, A.R., Faramarzi, M.A., and Setayesh, N., 2016. Enhancing activity and thermostability of lipase A from Serratia marcescens by site-directed mutagenesis. Enzyme Microb. Technol., 18: 93-94. https://doi.org/10.1016/j.enzmictec.2016.07.006

Nikaido, H., 2009. Multidrug resistance in bacteria. Annu. Rev. Biochem., 78: 119-146. https://doi. org/10.1146/annurev.biochem.78.082907.145923

Nwuche, C.O. and Ogbonna, J.C., 2011. Isolation of lipase producing fungi from palm oil Mill effluent (POME) dump sites at Nsukka. Braz. Arch. Biol. Technol., 54: 113-116. https://doi.org/10.1590/ S1516-89132011000100015

Pirt, S.J., 1975. Principles of microbes and cell cultivation. Blackwell's Sciences, Oxford, London, UK, pp. 4-22.

Ramos-Sanchez L.B., Cujilema-Quitio1, M.C., JulianRicardo1, M.C., Cordova, J. and Fickers, P., 2015. Fungal lipase production by solid state fermentation. J. Bioproc. Biotechnol., 5: 203-212. https://doi.org/10.4172/2155-9821.1000203

Riyadi, F.A., Alam, M.Z., Salleh, M.N. and Salleh, H.M., 2017. Optimization of thermostable organic solvent-tolerant lipase production by thermotolerant Rhizopus sp. using solid-state fermentation of palm kernel cake. 3 Biotech., 7: 300.

Snedecor, G.W. and Cochran, W.G., 1980. Statistical methods. (7th Ed). Iowa State University, Iowa, USA. pp. 32-43.

Van, A.M.V., 1998. Mutation breeding: Theory and practical application. Cambridge University Press, London, UK, pp. 152. 